\title{
ATTENTION DEFICIT HYPERACTIVITY DisORDER (ADHD) Portrayed In Robin Roe's Novel A LIST of CAGES
}

\author{
Vivi Marianti Butar-Butar, Parlindungan Purba, Siamir Marulafau \\ English Department, Faculty of Cultural Studies, University of Sumatera Utara
}

vivimbb@gmail.com

\begin{abstract}
This thesis discussed about the symptoms Attention Deficit Hyperactivity Disorder (ADHD) in the novel A List of Cages by Robin Roe. This thesis aimed to find out how the symptoms of ADHD are described through the leading character in the novel. This thesis used to describe the core symptoms of ADHD, namely: Attention, Impulsivity, and Hyperactivity. There are symptoms of ADHD that Adam has, namely: Attention symptom is easily bored; Impulsivity symptom is agitated; and the Hyperactivity symptom is: do excessive motor activities. This thesis used Russell Barkley's theory to analyze the symptoms in a novel using Literary Psychology. In analyzing this thesis, the writer used a qualitative descriptive method that presents all data in the form of words and sentences and uses library research as a way to collect data by reading and selecting quotations from the novel A List of Cages. From this research it is found that the leading character in the novel experienced all the three core symptoms of ADHD.
\end{abstract}

Keywords: $A D H D$, literature, attention, impulsivity, hyperactivity

\section{INTRODUCTION}

Attention Deficit Hyperactivity Disorder (ADHD) is a developmental disorder of behavior that causes sufferers unable to concentrate and become hyperactive. This disorder generally affects children and can even continue into adulthood. This condition can also affect the lives of sufferers both in their environment and social relationships.

Attention Deficit Hyperactivity Disorder (ADHD) is also a neuro-biological disorder in a child's brain. ADHD symptoms in adolescents are different from children. It can be found that actually not a few who experience ADHD from children continue into adulthood. ADHD is a chronic disease which begins in childhood with an estimated worldwide prevalence rate for children and adolescents of $5 \%$ and 3in adults. The symptoms of ADHD often tend to last from adolescence into adulthood and until old age. This has been confirmed in long-term follow-up studies which have demonstrated the persistence of symptoms in many adults diagnosed with ADHD in childhood (WADA, 2017:1).

The symptoms of ADHD in male and female adolescents are different. ADHD usually experienced by male adolescents will give a picture of behavior such as difficulty sitting still in a chair. They will sit in an unusual position such as rocking a chair or kicking their legs to make a noise. Conversely, adolescent girls with ADHD do not necessarily do that too. Even though they did not survive sitting long in the chair, young women could channel their desire to move by going around or moving from one table to another without disturbing others, and so on. The symptoms of ADHD consist of three parts, they are: attention, impulsivity, and hyperactivity. Attention in ADHD symptoms refers to the difficulty to focus attention such as lack of concentration, easy to switch attention, difficult to organize, forgetful, etc. Impulsivity refers to the difficulty of delaying the response because there is an impulse based on conscious or unconscious wishes such as impatience, reactive, often acting without thinking, making careless mistakes, etc. Hyperactivity refers to a behavior that is excessive or incompatible with development, both motor and vocal activity. This hyperactivity behavior is characterized by behaviors that cannot be silent, such as talking a lot, cannot be calm / silent, etc.

An example of ADHD phenomenon that can be seen in life is Adam Levine. He is a world musician who turns out to have suffered from ADHD as a child. In an interview on a television program, Adam told how he had struggled to overcome ADHD since he was a child. Thanks to his tenacity, Adam has now become one of the most influential musicians in the world. He also proved that this is not really a bad thing, much less inhibiting the achievement. Those who suffer from ADHD should not feel different from others, instead making motivation to be better.). Based on the phenomena, the author is interested in bringing up the topic of ADHD to be the thesis title taken from the novel A List of Cages because even a famous figure has had ADHD.

A literary work can be analyzed in several ways; one of them is through the approach of literary psychology. Psychology Literature is an approach that considers the psychological aspects and concerns the inner human, because literature and psychology are studying the psychological state of others. Wellek and Warren (1949: 81) said in their book Theory of Literature "Psychology can enter to literature 
by studying the psychology of the writer, psychology of the character, and also psychology of the reader." Based on what Wellek and Warren said, it can be concluded that psychology and literature are related to each other. Psychology can enter literature because the author uses his feeling and emotion in creating work as happens in novel.

Robin Roe is an American writer of a novel A List of Cages.. The story line of her novel is searingly personal to Roe, who grew up in Denison amid what she describes as rough circumstances. Then, as a teenager, Roe and her mother took over raising three of her nephews. One of her nephew suffers from ADHD. Thus, she was inspired to write the novel A List of Cages because it comes from her own experienced. This is becoming the background and reason for the writer interested in discussing ADHD because Robin Roe has references to ADHD from the experience of his own nephew who has ADHD and this is depicted in her novel, so the writer believes that Roe described ADHD according to the experience she saw directly.

A List of Cages tells the story of an eighteen year old boy named Adam Blake who suffered from ADHD since childhood. Adam is a high school student. He has many friends and also liked by his friends and teachers. Adam is a character who is kind and has deep empathy towards others, so he makes people around him feel comfortable. Besides that, Adam had to live side by side with his ADHD, which often gave rise to excessive behaviors unlike normal children as it should be, such as being unable to be quiet, disturbing / nosy towards his friends, often running and jumping at will even stumbling over his own feet. He also feels bored quickly so that he cannot last a long time in an activity. Even though Adam's behavior seemed abnormal, the ADHD he suffered did not make him into a bad teenager but rather a person who liked by many people.

This study aimed to discover the psychological elements, which portrayed as Attention Deficit Hyperactivity Disorder (ADHD) in Robin Roe's novel. Knowing what is ADHD and its symptoms will give a good benefit in social life because when the symptoms are experienced / found, people who have knowledge about ADHD will be more sensitive to this disorder. This study hoped that it will give some knowledge about ADHD described in the novel as a social life reflection.

\section{MATERIALS AND METHODS}

In this study, the writer uses a library research and descriptive - qualitative research. It analyzes all the data are in the form of words and sentences. The analysis involves the description of ADHD symptoms as portrayed in the novel. First, the writer reads the novels, A List of Cages, and then finds out the problems that the main characters have to face in the story. The second is to collect the materials and classify the symptoms of ADHD as portrayed in Robin Roe's A List of Cages. The sources of data are divided into two parts, they are primary data and secondary data. The primary data can be derived from the novel which will be the main data.The secondary data can be derived from the books, the articles of journals or other source of materials that related to the topic of Psychology Literature and the concept of ADHD.

To determine the symptoms of ADHD of the leading character in the novel, first step is read the whole story of the novel, as the data source in this thesis to get the comprehension deeply. The second step is the writer chooses and finds the problems in the novel to discuss in the analysis as the research. After that, the writer selects and picks the data, which are the quotations of the words, phrases, sentences, and paragraphs in the novel that relate to the problem. Then, the writer finds some information in books, journals, electronic book, and articles that related to psychology literature and ADHD. Lastly, the writer makes interpretation based on the novel which already read before.

Data analysis is applied when all the data from the novel is collected and selected. The data from the novel is in a form of written text, which concern about the symptoms of ADHD. After that, the writer will make interpretation based on the data which already taken before. The writer will analyze the data focusing on the leading character's symptoms of ADHD those are Attention, Impulsivity, and Hyperactivity in novel A List of Cages by Robin Roe.

\section{RESULTS AND DISCUSSION}

The writer found that there are three symptoms of ADHD experienced by Adam Blake in A List of Cages novel, they are: Attention, Impulsivity, and Hyperactivity. Attention symptom of Adam is easily bored. The feeling of boredom is present because he cannot focus his attention on one activity appropriately. In the second symptom, the impulsivity symptom is easily agitated. The symptom appears based on doing something without thinking about the consequences of what will happen in the future. 
Hyperactivity symptom of Adam is doing excessive motor activities that is jumping and running. The symptom is present because he fails to regulate or control activities according to the situation. Jumping and running occurs because of Adam's inability to control himself to try something based on his curiosity.

\subsection{AtTEnTiON}

Attention refers to a disorder of difficulty maintaining attention and focus on a particular activity. The difficulties experienced by adolescents with ADHD are caused by stimuli that approach their attention so that their concentration is easily disturbed. These disturbing stimuli can be present through what they hear, see, feel, and smell. This disorder can occur in various situations such as in the academic and social fields. Thus, adolescents who suffer from ADHD will spend a lot of energy to be able to maintain their attention to certain things.

Difficulties in concentrating the attention that ADHD adolescents experience naturally also make it easy for them to switch from one activity to another. This condition is most often seen when they are carrying out work that is boring or less attractive to them both school work and homework. Like when they are in school, they are not only listening to the teacher, but they will also be distracted by hearing sounds such as the sound of moving cars, the sound of birds, and even they also like to see pictures on the wall, imagining, and so on. In essence, they have difficulty pushing stimuli that come away from their consciousness. In the novel A List of Cages, Adam has symptom of Attention that is easily bored.

ADHD is portrayed on Adam Blake as the main character in this novel. Adam is described as having Attention symptoms from ADHD, which is quickly or easily bored. Boredom is a common thing that is felt by everyone. Generally, it is a condition where someone feels uninterested in the surroundings because nothing can be done. Boredom can occur due to many things. It could be because of doing a monotonous activity, meeting the same people continuously; doing something that is not liked, and so on. Those with ADHD quickly become bored with something because they can't stand in certain situations, so that they feel confined within themselves. When they try to focus and maintain attention to something, they will need a lot of energy. In addition, activities that take too much of their attention also cause them to get bored quickly, so they are easily distracted in any other activities such as waiting, doing school assignments, doing repetitive activities, and so on.

He doesn't look convinced, but he steps back enough to let me jump through the narrow passageway. When I make it, Julian's wearing this hopeful smile, so I say, "This is cool." But it's not cool. It's practically a closet, one that was burned and rebuilt but still smells like it's rotting. "You eat lunch here every day?"

He nods. That's even more depressing than this room. We've been up here for less than two minutes, but already I'm feeling bored and caged. I pace the floors, look out the little window, then pace some more and end up stubbing my foot on something - a stack of composition notebooks stuffed into the corner.

(Robin Roe, 2017:110)

In the quotation above, Adam feels a feeling of being bored in a room that he first visited. The room is the usual place for Julian to eat lunch which in fact the place looks unfit to live in, because it looks like a closet that had been rebuilt. People who are bored tend to do other things to get rid of their boredom. In this case Adam did so. The feeling of boredom experienced by Adam made him feel caged so he does activities to divert his boredom by pacing and looking out the small window. In addition, someone generally feels bored because they are already in a long enough situation or condition to cause discomfort in him which ultimately forces himself to do a new activity. In the quotation above, Adam does not act like a normal person, he feels bored being in the room for a period of two minutes which is actually a very short time to make someone feel bored quickly. It should be strange to immediately feel bored within two minutes. This proves that ADHD suffered by Adam affects the feeling of being easily bored because he cannot focus his attention properly on an activity.

\subsection{IMPULSIVITY}

Impulsivity refers to the difficulty to delay the response due to impulse which is based on conscious desire or unconsciousness which is marked as acting without thinking. This condition is called also occurs when someone gets the urge to take an action without thinking of the consequences first. Adolescents with ADHD are usually very impulsive. They will do something based on their will and 
what comes to mind. They don't even care if it brings good or bad. This is because it is difficult for them to regulate their own behavior, because their control system is different from other normal adolescents.

Impulsivity symptoms can be in the form of uncontrolled behaviors so that they tend not to be able to delay the response. Their inability to control themselves can appear on many occasions, both from trivial things to big things. Adolescents ADHD with impulsivity can say or do something that is inappropriate and then regret it. In essence, they often make mistakes that should not have happened, and when they are asked what the reason of doing it, they tend not to know the reason. Impulsivity has three parts of symptoms, namely; behaviorally, cognitively, and emotionally. Adam experienced the symptoms of behaviorally that agitated.

Adam in this novel has symptoms of emotional impulsivity which is easily agitated. Agitated is something that describes if a person is not calm in his heart or actions not calm in behaving, impatient or in anxiety. Agitated can also be interpreted as worry or fear. It is also related to frustrating problems, which by definition can be mentioned, that someone experiences frustration because what is desired is not achieved. In general, someone who is restless will show behavior or movements such as walking back and forth, moving the body, pensive, and so forth. They tend to behave this way because they feel uncomfortable or not calm against a certain condition. The following is a quote that says Adam felt agitated:

The play is as awful as they ever were, so about five minutes in, I'm fidgeting.Charlie stomps on my foot.“Asshole." I wince, but this just seems to make him happy. Five seconds later, I'm squirming again, not intentionally trying to piss him off, but it's a nice side effect. As each terribly executed scene drags on, I get a little more agitated. I can't stop thinking about what Ms. Cross said, how she didn't want Julian to publicly humiliate himself. Maybe I made a mistake in pushing him. If it doesn't go well, who the hell knows what'll happen?

(Robin Roe, 2017:109)

In the quotation above, Adam felt anxious when the show started. He is nervous about the role that will be played by Julian. Anxiety through Julian was based on his unwillingness that Julian embarrassed himself at the show. So he thought too much that Julian might fail in playing his role. His anxiety was shown by showing gestures, namely stretching his body, which made his friend Charlie felt unhappy because it bothered him to enjoy watching the show. However, this cannot be avoided by Adam because his inability to control the response that comes as Charlie's response to anger does not reduce Adam's anxiety. His anxiety also stemmed from his actions which urged Julian to take part in the show so he had regretted urging Julian who in fact was aiming to make Julian aware that he was actually able to play that role.

\subsection{HYPERACTIVITY}

Hyperactivity refers to a behavior that is very excessive or not in accordance with the level of one's development both in the form of motor and vocal activity. This condition is also marked when a person becomes more active than usual. Symptoms of hyperactivity in adolescents that are often encountered such as unable to sit quietly not stop talking, hands and feet always moving, running around or climbing too much in an improper situation, and so on. Adolescents with hyperactivity generally can experience other problems as a result of the difficulties experienced. This certainly can cause difficulties for them in activities at school or home, and can even affect their relationships with family and friends.

Adolescents with ADHD must have spent a lot of energy in activities because they tend to behave excessively. The hyperactivity behavior that is often seen is showing excessive anxiety even though the situation is relatively calm, unable to be still, the body thoroughly moves, and also does not stop talking. Those behaviors often occur without purpose, which means it is not in accordance with the task or situation that existed at that time. This indicates that ADHD adolescents with hyperactivity symptoms fail to regulate or control activities according to the situation. In the novel A List of Cages, Adam experiences symptoms of hyperactivity they are; nonstop talking, do excessive motor activities, and disturbing other people.

At the age of adolescents generally can control their motoric activities. Motoric activity is the behavior of movements carried out by the human body that is why often jump and run is part of motoric activities. For adolescents who suffer from ADHD, controlling their motoric activities becomes a difficulty because of the symptoms of hyperactivity that can be felt without being prevented to behave 
following their instincts. Adam has symptoms of hyperactivity in the form of jumping and running. $\mathrm{He}$ did it repeatedly even though he already knew what the consequences would be come if he continued to do so.

In this case, Adam shows the symptom of doing excessive motor activities by jumping and running. Jumping and running is a movement involving members of the body. As we know, running and jumping is done by toddlers who do it because they want to explore what they see. Adam who was an adolescent did this to complete his curiosity. This then became the difficulty and failure of Adam as an adolescent of ADHD to organize activities according to the situation.

"I burst out laughing. "You're funny." I eye the brick wall, wondering if I could do that thing where you run up a wall and backflip.

"I won't get in trouble. She said we could just hangout.

"I take a leap and end up falling on my ass.

"Ow." I lie here while Julian cautiously sits on the wooden bench. "What are you doing later?"

(Robin Roe, 2017:51)

From the quotation above, Adam intends to do an abnormal thing which is to run up the brick wall and turn upside down. This is certainly not going to be done by normal adolescents considering there are no benefits at all to do that, but exceptions for those who suffer from ADHD. They will think it is a challenge that is worth to try without caring about the consequences that will be obtained. The thought of Adam who wanted to run and climb a wall came from his ADHD which he could not control, so he considered that if he did it, it was not a problem. But in the end, everything that was done must have risked the same thing as Adam who finally fell because climbing a brick wall. Even though he fell, it did not make Adam feel sorry for doing it because he did not care about the risks and most importantly his curiosity about whether he could run up the brick wall and turn upside down he could do, as evidenced by the response he just made and then lying down, because if someone else might immediately regret doing that.

\section{CONCLUSION}

Knowing the symptoms of ADHD in adolescents is not easy because the symptoms look like normal adolescents if they are not carefully studied. An adolescent is said to have ADHD if he / she has three types of symptoms, namely Attention, Impulsivity, and Hyperactivity. Based on the results of analysis and findings on ADHD symptoms of Adam Blake, the writer draws some conclusions in this thesis after having analysis from the leading character's ADHD symptoms of novel A List of Cages by Robin Roe. Attention, impulsivity, and hyperactivity are indeed three symptoms of ADHD. ADHD which generally occurs since children are also portrayed in the novel A List of Cages by Adam Blake. Robin Roe wrote this novel in a very epic way with extraordinary delivery so that it can be understood and the knowledge conveyed can be useful for the community as well. This novel tells how and what the symptoms of ADHD are actually seen which are very common as children behave in a known manner. Therefore, this novel is very good to be read by anyone, especially those who want to see the symptoms of ADHD.

\section{REFERENCES}

Jahja, Yudrik. (2011). Psikologi Perkembangan. Jakarta : Prenadamedia Group

Mindetrop, Albertine. (2016). Psikologi Sastra, Metode, Teori, dan Contoh Kasus. 2d ed. Jakarta: Yayasan Pustaka Obor Indonesia.

Pardede, Martha. (2016). Literature An Introductory Material. Medan : USU Press

Paternotte, Arga and Jan Buitelaar. (2010). ADHD Attention Deficit Hyperactivity Disorder (Gangguan Pemusatan Perhatian dan Jiperaktivitas) Gejala, Diagnosis, Terapi, serta Penanganannya di Rumah dan di Sekolah. Jakarta:Kencana.

Roberts, Colleen Alexander. (1995). ADHD \& Teens, A Parent's Guide to Making It Though Years. Lanham, MD : Taylor Trade Publishing.

Robin, Arthur L. (1998). ADHD in Adolescents, Diagnosis \& Treatment. New York: The Guilford Press. Roe, Robin. (2017). A List of Cages. New York : Hyperion 
Rusmawati, Diana, \& Endah Kumala Dewi. April 2011, "Pengaruh Terapi Musik dan Gerak Terhadap Penurunan Kesulitan Perilaku Siswa Sekolah Dasar dengan Gangguan ADHD." Jurnal Psikologi. Volume 9 , No

1,https://ejournal.undip.ac.id/index.php/psikologi/article/view/2913/2597, 3 Mar. 2019.

Saputro, Dwidjo. (2009). ADHD (Attention Deficit/Hyperactivity Disorder). Jakarta:Sagung Seto

Sehandi, Yohanes. (2014). Mengenal 25 Teori Sastra. Yogyakarta : Ombak.

Surastina. (2018). Pengantar Teori Sastra. Yogyakarta : Elmatera.

WADA - World Anti-Doping Agency. 2017. "Attention Deficit Hyperactivity Disorder (ADHD) in Children and Adults". TUE Physician Guidelines. Version 6.0 No1, https://www.wadaama.org/sites/default/files/resources/files/tuec_adhd_version6.0_august2017.p df, 24 Jan. 2019.

Warsiman. (2017). Pengantar Pembelajaran Sastra: Sajian dan Kajian Hasil Riset. Malang: UB Press

Weiss, G., \& Hechtman, L. T. (1993). Hyperactive children grown up: ADHD in children, adolescents, and adults (2nd ed.). New York, US: Guilford Press.

Wellek, Rene and Warren, Austin. (1949). Theory of Literature. New York: Harcourt, Brace and Company, Inc

Wicaksono, Andri and Emzir, et al. (Ed.). (2018). Tentang Sastra: Orkestrasi Teori dan Pembelajarannya.Yogyakarta: Garudhawaca. 
